\title{
Tarek Pukat Dance from Aceh: Representation of the Beauty of Coastal Culture
}

\author{
Joesana Tjahjani \\ French Department, Faculty of Humanities, Universitas Indonesia, Depok 16424, Indonesia \\ tjahjani.joesana@gmail.com
}

\begin{abstract}
Besides being famous for its culinary delights and exotic natural beauty, Aceh is also famous for traditional dances. Among the many dances originating from Aceh, Tarek Pukat is a dance that is often performed during traditional ceremonies or cultural events, both in domestic and international levels. Tarek Pukat dance has a deep meaning for coastal communities, especially for fishermen. The departure of the procession, throwing the net into the sea, drawing the net, and the even distribution of catch are included as a series of fishing activities. In this article, Tarek Pukat dance is read as text and analyzed using the semiotic structural approach of Roland Barthes. The seven or more Tarek Pukat dancers, traditional costumes and accessories, a series of dance moves, and a musical accompaniment are read as signs that represent the relationship and harmonious spirit of the cooperation between the coastal communities of Aceh.
\end{abstract}

Keywords: Aceh; Coastal Culture; Representation; Traditional Dance.

\section{INTRODUCTION}

Culture is a form of development of knowledge, beliefs, arts, morals, laws, customs, abilities and habits acquired by humans. Culture itself is obtained by humans through the learning process in their environment. Every culture is considered as a regional characteristic. The uniqueness of cultural diversity in Indonesia can foster a sense of human curiosity about life and one's experience in culture. Domestic and foreign tourists travel to certain regions or islands to find various traditions of society and culture that are found in tourism destinations. In such case, culture is a text that shows the identity of the area. Meanwhile, art is all inner manifestations and aesthetic experiences of humans using various media. Artworks created by humans can foster thoughts and experiences for other humans.

One of the forms of arts in Indonesia is dance. The diversity of dance is one of the riches of the archipelago. Each type of traditional dance in each region functions in accordance with the lifestyle of the people of the area. Based on its role in people's lives, the types of dance can be grouped into ceremonial dances, entertainment dances, and spectacle dance. Dance contains 
meaning because it is created from a creative process, which is a human response to the dynamics of human life in the universe.

The purpose of this paper is to find the meaning of Tarek Pukat dance through the reading of the structural semiotics of Roland Barthes. Barthes made a systematic model in analyzing the meaning of the signs, one of the important areas that Barthes penetrated in his study of signs was the reader. Barthes reviews what is often referred to as the second level meaning system at length, which is built on other existing systems. Barthes called this second system the connotative while the meaning of the first level is called the denotative. The semiotic method is used as a tool to research nonverbal messages.

Barthes' semiotic approach [1] is used as an analytical tool to read Tarek Pukat dance as a sign by looking into the presence of Tarek Pukat dancers, traditional costume, series of dance moves, and accompanying music. Tarek Pukat is one of the art forms which become a cultural manifestation of the coastal communities of Aceh that holds a sense of beauty, which is a product of motion, poetry, and music. Each component of the dance has local wisdom that has meaning, messages about social norms, cultural values, and becomes a form of culture that regulates the social system in managing the activities in the social life of the community. Therefore, the dance is a vehicle of communication in conveying information about matters relating to life both related to social, economic, ritual or religious aspects, as well as problems related to nature and the creator of nature.

In many cultures and spiritual traditions, dancing is practiced as a method to come closer to the spirit and encounter the divine, and an expression of that existing relationship. [...] Dancing can be still, quiet, receptive and reflective, as well as exuberant and celebratory. It includes all aspects of the body-heart-mind unity or continuum, each of which finely influence and affect each other [2]. Dance is a medium of expression to convey moral messages, social reality, establishment, and spiritual education. Dance is the expression of the feeling of the human soul expressed through beautiful rhythmic movements and accompanied by music. Dance is a tool of expression or an artist's means of communication to others. Dance is also a means of expression because dance can create strands of motion that can sensitize the audience to phenomenon around them.

In relation to the Tarek Pukat Dance, in Acehnese language, Tarek Pukat is an activity of fishing with nets. This activity takes place in the coastal area, which is a routine of the fishermen. Tarek Pukat is very embedded with Acehnese culture because Aceh is surrounded by coastal areas. In addition, Tarek Pukat is a regional dance that describes the trawl fishing activities. This dance was created by the late Yuslizar Banda Aceh in 1962 [3]. Tarek Pukat describes the activities of fishermen who catch fish at sea. Tarek means pull and Pukat is a type of net used for fishing. This dance depicts the lives of fishermen on Aceh's coast including making nets and rowing boats. The movement is dynamic and cheerful with the accompaniment of traditional musical instruments [4].

Tarek Pukat dance is inspired by the tradition of fishing for Acehnese fishermen when they attract trawlers in the sea In its essence, every movement in the 'trek trek' dance recounts the daily life of the people in the coastal shore and making a living by becoming a fisherman. The life of the fishermen's family is embodied in this dance.

Based on the background described, this paper will examine Tarek Pukat dance through the presence of female dancers, traditional costumes, dance movements, and music that accompany the dance. Various elements that construct the structure of the Tarek Pukat dance 
are signs that represent the coastal culture of Acehnese society. The main question as well as the focus of the study in this paper is: how do the elements of the Tarek Pukat dance's structure present a coastal cultural identity in Aceh? Some subordinate questions that arise are: what is the meaning of the presence of female dancers in the Tarek Pukat dance which is describing the activities of men in coastal communities in Aceh? How can the other elements in Tarek Pukat dance, such as dance movements, music, and traditional costumes be read as a sign that represents a beautiful and harmonious spirit between the coastal communities of Aceh?

\section{METHOD}

Qualitative research is an approach for exploring and understanding the meaning individuals or groups ascribe to a social or human problem. The process of research involves emerging questions and procedures, data typically collected in the participant's setting, data analysis inductively building from particulars to general themes, and the researcher making interpretations of the meaning of the data [5]. Semiotics is a science or method of analysis to examine signs, in the form of devices or symbols. Signs are mental images, thoughts, or concepts. In the general sense, denotation is usually described as a literal meaning, the real meaning. Whereas in the level of signification, denotation explains the relationship between the sign and its reference to the reality and presents explicit, direct and definite meanings. Denotation is a direct meaning. In Barthes's understanding, myth is a communication system, a message is not an object, idea, or concept, it is a model of designation, a form. According to Barthes [6], "Myth is not defined by the object of the message, but by the way in which the object conveys the message. Myths can come from written or written discourse, written coverage, published books, etc. or even pictorial representations, photographs, films, sports, as well as performances, because myths convey messages, then by themselves, they are part of a semiological system which involves signification, according to Barthes, myth is a second-ordersemiological system sign (an associative relationship between images and concepts) in the first system (denotative-connotative) is merely a signifier in the second system."

\section{RESULT AND DISCUSSION}

\subsection{Interpretation of Meanings on Tarek Pukat Dancers and Dance Movements}

Tarek Pukat Dance is usually performed by 5-9 female dancers, and 4 or 5 male dancers. In the original Tarek Pukat dance, female dancers are present first and then followed by the male dancers. The male dancers are behind the female dancers to demonstrate their movements at sea, starting from paddling the boat, catching fish up until they put the caught fish into the basket. Meanwhile, the female dancers, who are in the front row, sit down and demonstrated how to make trawls until they scatter at the end of the dance. One by one, the female dancer moves the knitting trawl by wrapping the rope, which is tied to her waist, to the dancer next to it. The movement happens repeatedly until they finally trawl seams. The movement looks simple, but it actually requires high compactness and focus. While sitting, there is a trawl making process that becomes a symbol of this dance.

As it is known, fishing activities are activities to make a living which is generally carried out by men. The existence of female fishermen is almost never heard of. In this context, the sea is a symbol that symbolizes masculinity, while women are metaphorically ashore, which is the place where fishermen return. 
This is on the contrary to the existence of female dancers who dominate the dance of Tarek Pukat, a dance that symbolizes fishing activities. The existence of female dancers in this dance seems to break the myth that women, as the weaker sex, cannot play a role in subsistence activities in coastal areas. Women in Tarek Pukat can be said to represent the beauty and spirit of togetherness of the coastal communities of Aceh.

As has been revealed, Tarek Pukat dance consists of a series of movements which are essentially related to fishing activities in coastal communities in Aceh, starting from rowing movements, tying boat ropes, putting fish into baskets, all the way to the trawling movements. The two movements in Tarek Pukat that express the cooperation of fishermen when catching fish in the sea are Kayoeh, which is a rowing boat and Ikat Taloe movement or a movement to tie a boat. In addition, the Pasoe Engkot Lam Raga movement demonstrates the activities of the fishermen when pilling the caught fish into the basket. Meanwhile, the Bahue Pukat movement, which means carrying trawlers, exhibits how to make and carry trawls. This movement is the core movement of Tarek Pukat dance, as indicated by the name of dance.

The strong influence of Islam causes the mindset, attitudes, and behavior of Acehnese people in their daily lives to be adapted to the rules of Islam wherever possible. Likewise, cultural life and the art of Acehnese society are full of various symbols that refer to the practice of worship in the Islamic religion. In addition to reflecting the spirit of togetherness and mutual cooperation, Tarek Pukat dance cannot elude the influence of Islam. Head-shaking movements, for example, describe the movement of the head during prayer. In addition, the way Muslims sit in their prayers is also illustrated by the sitting position when performing prayers.

\subsection{Interpretation of Meanings on Tarek Pukat Dance Costume and Music}

In the costumes used by the dancers, there is a nonverbal communication where the cultural values are conveyed. The series of messages on costumes, both motifs and colors, and accessories in Tarek Pukat dance are artefactual messages from Tarek Pukat dance. The costume used by the dancers in the Tarek Pukat dance performance is usually traditional clothing. The dancers usually use clothing such as long-sleeved shirts, trousers, and headscarves. In addition, dancers also use songket and belts at the waist and veil decorations to attract the audience. In Système de la mode[7], Barthes elucidates the fashion world at length. In this book, Barthes also discusses the signifier operation mode, the signified structure, and the sign structure or significance. Indeed, the study of fashion or Barthes' fashion is inseparable from the field of semiotics that had been developed.

In the art of dance, costumes can be used as an identity. Tarek Pukat dance's costume is uniquely made, both in design and shapes. The costume stylist has a big role in contributing to the color and harmony in Tarek Pukat dance's clothing. There is no standard form and color in the Tarek Pukat dance. They have two different clothes between male and female dancers. Therefore, it can be inferred that the fashion images used in the Tarek Pukat dance carries meanings. Analyzing the clothes used in this dance, Acehnese songket clothes are typical of Aceh's long-sleeved clothes. This shirt is used to cover the upper body to look modest. In the science of semiotics, this can be said as an icon and code, which explains, that Aceh is an area whose people cling to Islam. Further analyzing the songket, which is worn as a bottom garment, it is found that songket is used to cover inner trousers that are usually thinner. This means that the fabric to cover the body shape of the waist down so as not to appear to show the silhouette due to using black pants with stretchy materials such as leggings which are generally tighter and 
showing the shape of the body. This is also a representation that the Acehnese people are very obedient in carrying out the rules in the Islamic religion, especially the women. This strong culture of Islam is intended to cover women's genitals by using additional pants in songket. After being covered by songket fabric from the hips to the knees, the shape of the body from the buttocks to the knees will be covered up.

Examining the colors of the clothes in the Tarek Pukat dance, Tarek Pukat's costumes' color for women is a blend of pink, gold, and a little black accent. Pink and gold are more dominant in dance clothes worn by women. Blue has a soft, graceful and cool meaning. While the golden color symbolizes health, safety, joy, wisdom, meaning, purpose, the heart's search, mystical power, science, feeling of awe, and concentration. Those things above could be found in Barthes' explanation, in Système de la mode (The Fashion System) [7] which is not the easiest reading material. For experts in semiotics, fashion or clothing, colors can be categorized as a language and can be used as a communication contract or to convey a message. Communication uses fashion and clothing as a form of message or to convey meaning. This is what nonverbal communication can be understood as, a condition in which the language of speech is not used as a way to convey the message. As time goes by, fashion that is now regarded as a trend that is constantly changing and more fun proves to have a deeper meaning and greater influence in a person's life. Fashion has become part of everyone's self-awareness and is no longer just about the external appearance. The style of a person depends on who uses it.

Besides dancer costumes, music can be read as a sign in Tarek Pukat dance. The musical accompaniment of Tarek Pukat dance comes from several traditional Acehnese musical instruments, namely Serune Kalee, Geundrang, and Rapai. Serune Kalee is a wind instrument that is usually played as the main musical instrument in traditional music performances in Aceh. In Tarek Pukat dance, Serune Kalee is the only melodic instrument that produces tones. The two other musical instruments in Tarek Pukat, Geundrang and Rapai, are percussion instruments which are beaten by hand. Both are rhythmic musical instruments that are played together and function complementarily to keep the atmosphere lively.

\section{CONCLUSION}

Tarek Pukat is a dance work created according to imagination the choreographer, but this dance does not only emphasize on performance and entertainment. Tarek Pukat dance is a dance that can interpret all aspects of life in the Acehnese community. The use of semiotic theory can prove that the myths are the dance is togetherness in Acehnese society. In Tarek Pukat's structure, each dancer prioritizes motion compactness. Then with the arrangement of Tarek Pukat, the dancers find their respective positions, dance by following the leader's movements, and working together in forming a net. This represents togetherness and mutually helping each other in Acehnese society.

In analyzing the Tarek Pukat dance, it may be concluded that, a dance, such as Tarek Pukat, has a social function in the form of language, as a communication tool. In this case, the elements of the dance convey the message. This dance is a representation that a work of art can be used as a medium to convey information to the wider community. There is a message in the presence of the female dancers. It shows the tenacity of Acehnese women, who are not inferior to men in Aceh region. This tarek trawler dance movement is taken from the daily lives of coastal communities whose livelihood depends on their role as traditional fishermen. If the 
movement is facilitated or interpreted one by one, it cannot be understood holistically. Dance movements that are the work of creative artists contain beauty.

Besides examining the movements in Tarek Pukat dance, another conclusion to infer is the representation of the costume, which is worn by female dancers, which can be used as gestural messages in dance that have certain meanings. Clothing is an important expression for creating meaning and a form of communication. The meaning of this outfit is to teach the community to keep fighting hard to fulfill their needs, radiating strength in survival for male dancers and giving a gentle, graceful and elegant impression for female dancers. Meanwhile, the costume of the male dancers represents the toughness to face nature.

Tarek Pukat dance is a form of nonverbal language to convey moral messages to the public or the audience. The representation in Tarek Pukat dance, through the presence of dancers, dance movements, musical accompaniment, and costume, describes the lives of Acehnese people, especially those who are located or domiciled around the coast who together or collaborate in earning a living for themselves and their families.

\section{REFERENCES}

[1] R. Barthes, "Éléments de sémiologie,” Communications, vol. 4, pp. 91-135, 1964.

[2] E. Kieft, "Dance as a moving spirituality: A case study of Movement Medicine," Danc. Mov. Spiritualities, vol. 1, no. 1, pp. 21-41, Jan. 2014.

[3] F. Burhan and Z. Idris, Ensiklopedia Musik dan Tari Daerah, Propinsi Daerah Istimewa Aceh. Banda Aceh: Pusat Penelitian Sejarah dan Budaya, Proyek Inventarisasi dan Dokumentasi Kebudayaan Daerah, 1986.

[4] Z. Idris, Peralatan Hiburan dan Kesenian Tradisional Propinsi Daerah Istimewa Aceh. Jakarta: Proyek Penelitian, Pengkajian, dan Pembinaan Nilai-nilai Budaya, 1993.

[5] J. W. Creswell, Research Design: Qualitative, Quantitative, and Mixed Methods Approaches. Los Angeles: Sage Publications, Inc, 2014.

[6] R. Barthes, Mythologies. Paris: Editions du Seuil, 1957.

[7] R. Barthes, Système de la mode. Paris: Editions du Seuil, 1967. 